\title{
Effect of isopsoralen on Smad7 in osteoblastic MC3T3-E1 cells
}

\author{
HUICUN ZHANG ${ }^{1,2}$ and NA TA ${ }^{3}$ \\ ${ }^{1}$ Department of Combination of Traditional Chinese and Western Medicine, Beijing Hospital of Traditional Chinese Medicine, \\ Capital University of Medical Sciences; ${ }^{2}$ Department of Pathological and Physiological, \\ Beijing Institute of Traditional Chinese Medicine, Beijing 100010; ${ }^{3}$ Department of Public Health and Risk, \\ China National Health Development Research Center, Beijing 100019, P.R. China
}

Received April 29, 2016; Accepted March 31, 2017

DOI: $10.3892 /$ etm.2017.4688

\begin{abstract}
The primary pathological change in postmenopausal osteoporosis (PM-OP) is bone collagen loss caused by estrogen depletion. Osteoblasts synthesize type I collagen, which composes the organic matrix of bone. Although isopsoralen stimulates osteoblastic cell proliferation and differentiation, transforming growth factor (TGF)- $\beta 1$ is an important cell signaling factor for stimulating collagen synthesis. To explore the association between isopsoralen and the synthesis of collagen in vitro, the molecular and biological association between isopsoralen and TGF- $\beta$ signaling was examined. (CAGA) 12-luciferase-reporter gene was used to measure TGF- $\beta 1$ signaling activity. Type I collagen was detected by semiquantitative reverse transcription polymerase chain reaction, and mothers against decapentaplegic homolog 7 (Smad7) protein expression levels were analyzed by western blotting. The expression of collagen in MC3T3-E1 cells stimulated with isopsoralen was significantly upregulated compared with the control groups $(\mathrm{P}<0.05)$. Conversely, isopsoralen significantly decreased Smad7 protein expression compared with the control groups $(\mathrm{P}<0.05)$. Moreover, it was observed that isopsoralen activates the TGF- $\beta 1$ signaling pathway and ultimately promotes collagen synthesis through inhibition of Smad7 protein expression. Therefore, isopsoralen is a potential target for the treatment of PM-OP.
\end{abstract}

\section{Introduction}

Postmenopausal women are prone to develop postmenopausal osteoporosis (PM-OP), which is caused by estrogen deficiency after menopause (1). The primary pathologic

Correspondence to: Dr Huicun Zhang, Department of Combination of Traditional Chinese and Western Medicine, Beijing Hospital of Traditional Chinese Medicine, Capital University of Medical Sciences, 23 Art Gallery Backstreet, Beijing 100010, P.R. China

E-mail: zhanghuicun728@126.com

Key words: isopsoralen, postmenopausal osteoporosis, MC3T3-E1, type I collagen, mothers against decapentaplegic homolog 7 change caused by PM-OP is bone collagen loss as a result of estrogen depletion, which subsequently stimulates imbalanced bone remodeling (2). Osteoblasts synthesize type I collagen, which composes the primary organic matrix of bone (3). Transforming growth factor (TGF)- $\beta 1$ has an important role in cell proliferation, differentiation and apoptosis, as well as bone collagen synthesis (4). The TGF- $\beta 1$ signaling pathway is initiated by ligands that bind to TGF- $\beta$ receptors, which activate the transfer of intracellular mothers against decapentaplegic homolog (Smad) proteins into the nucleus and transmit the signal (5). Once TGF- $\beta$ receptors are activated by ligands via the phosphorylation of Smad family members, TGF- $\beta$ receptor type I (T $\beta R \mathrm{R}$ ) initiates signal transmission (6). At present, eight types of Smad proteins have been identified in mammals (7) Smads are divided into three categories based on their structure and function: Receptor-regulated Smads, which include Smad2 and Smad3; common-mediator Smads, which include Smad4; and inhibitory Smads, which include Smad6 and Smad7 $(8,9)$. Increased TGF- $\beta 1$ expression is accompanied by increased Smad2, Smad3 and Smad4 expression, as well as cell proliferation in in vitro cultured osteoblasts (10). Research regarding Smad7 is comparatively limited. Type I collagen is an important gene for determining bone mineral density and osteoporosis predisposition (11). Human bone is primarily composed of collagen, which determines bone strength and quality (12). Type I collagen is the most abundant type of collagen found in bone and constitutes $\sim 95 \%$ of the entire collagen content of bone (13).

Osteoblasts are a vital type of cells in bone tissue and are important for the maintenance of normal bone mass and bone formation. The function of osteoblasts is associated with proliferation, differentiation and mineralization in the bone formation process and in alternative bone structure-associated processes (14). Osteoblast proliferation and type I collagen secretion may be either increased or reduced through the TGF- $\beta /$ Smad signaling pathway (10). Smad7 is an important factor in the negative feedback loop of the TGF- $\beta / \mathrm{Smad}$ signaling pathway and has an inhibitory effect on TGF- $\beta$, activin and the bone morphogenetic protein signaling pathway (15).

A previous study has demonstrated that inadequate secretion of ovarian hormones is the primary cause of osteoporosis (16). A number of studies have suggested that the inhibitory mechanism of estrogen in osteoporosis occurs through the 
proliferation of osteoblasts and the promotion of collagen secretion (17-19). Phytoestrogens exist in a large variety of plants and are structurally similar to estrogen (20) Previous studies have demonstrated that phytoestrogens improve and protect mineralized skeletal bone remodeling $(21,22)$. Fructus Psoraleae, which is the fruit of Psoralea corylifolia L., is a principal traditional Chinese medicine and is included in the Chinese Pharmacopoeia $(23,24)$. Isopsoralen is a derivative of Fructus Psoraleae and is considered one of the active components of the herb (25). Psoralen exhibits estrogenic activity that significantly promotes MCF-7 cell proliferation (26).

Isopsoralen is the active ingredient of psoralen, and the present study examined the effect of isopsoralen on pre-osteoblasts. Isopsoralen is a type of phytoestrogen that promotes cultured MC3T3-E1 cell proliferation and differentiation (27). However, at present, the underlying mechanisms by which isopsoralen promotes the TGF- $\beta$ signaling pathway in osteoblasts in vitro has not been reported. The present study aimed to observe the effect of different concentrations of isopsoralen on MC3T3-E1 cell viability, TGF- $\beta 1$ reporter gene activity and type I collagen and Smad7 protein expression. Additionally, the mechanism by which the phytoestrogen, isopsoralen, prevents and treats primary osteoporosis was investigated. The results of the present study reveal the mechanisms of the functional estrogen-like effects of isopsoralen and have applications to clinical gynecological medicine, particularly for postmenopausal women with osteoporosis.

\section{Materials and methods}

Experimental cells. Murine pre-osteoblast cells (MC3T3-E1) were cultured in DMEM (Hyclone; GE Healthcare Life Sciences, Logan, UT, USA) supplemented with $10 \%$ fetal bovine serum (FBS; Hyclone; GE Healthcare Life Sciences) in an atmosphere containing $5 \% \mathrm{CO}_{2}$ at $37^{\circ} \mathrm{C}$. MC3T3-E1 were purchased from the Cell Center of the Institute of Basic Medical Sciences Chinese Academy of Medical Sciences (Beijing, China).

Primary reagents and drugs. Isopsoralen was obtained from the National Institutes for Food and Drug Control (Beijing, China). Dulbecco's modified Eagle's medium (DMEM) and FBS were purchased from Hyclone (GE Healthcare Life Sciences). The following reagents were also utilized: RNA extraction reagent and TRIzol reagent (both from Invitrogen; Thermo Fisher Scientific, Inc., Waltham, MA, USA); GoldView nucleic acid stain (Promega Corp., Madison, WI, USA); diethylpyrocarbonate (DEPC) water, 6X DNA loading buffer and 5X Tris-acetate-EDTA solution (SBS Genetech Co., Ltd., Beijing, China); upstream and downstream primers (Invitrogen; Thermo Fisher Scientific, Inc.); M-MLV reverse transcriptase $(200 \mathrm{U} / \mu \mathrm{l})$, M-MLVRT $5 \mathrm{X}$ reaction buffer and RNA enzyme inhibitors (all from Promega Corp.); Taq DNA polymerase $3 \mathrm{U} / \mu \mathrm{l}, 10 \mathrm{X}$ reaction buffer (with $\mathrm{MgCl}_{2}$ ), and $10 \mathrm{mM}$ dNTPs (pH 7.5; all from Takara Biotechnology Co., Ltd., Dalian, China); and isopropyl alcohol, chloroform, anhydrous ethanol (analytically pure), streptomycin sulfate, penicillin, (all from Beyotime Institute of Biotechnology, Haimen, China). Anti-Smad7 (sc-11392) and anti-GAPDH (sc-365062) antibodies were purchased from Santa Cruz
Biotechnology, Inc. (Dallas, TX, USA). Polyclonal horseradish peroxidase-conjugated goat anti-rabbit (ZB-2308) and rabbit anti-mouse (ZB-2305) immunoglobulins were obtained from Beijing Zhongshan Golden Bridge Biotechnology Co., Ltd. (Beijing, China).

Cell viability assay. The effect of isopsoralen on MC3T3-E1 cell viability was detected by the MTT method. MC3T3-E1 cells were seeded in 96-well plates at density of $\sim 3 \times 10^{3}$ cells/well. When cells adhered to the plate, serum-free DMEM was added and the cells were incubated at $37^{\circ} \mathrm{C}$ in a humidified atmosphere containing $5 \% \mathrm{CO}_{2}$ for $24 \mathrm{~h}$. After $24 \mathrm{~h}$ in serum-free culture medium, cells were cultured in DMEM with $10 \%$ FBS containing $0,0.1,0.01,0.001$ or $0.0001 \mu \mathrm{M}$ isopsoralen for $72 \mathrm{~h}$ at $37^{\circ} \mathrm{C}$ in an atmosphere containing $5 \% \mathrm{CO}_{2}$. Subsequently, $4 \mathrm{mg} / \mathrm{ml}$ MTT solution in PBS was added to each well. Following incubation for $4 \mathrm{~h}$ at $37^{\circ} \mathrm{C}$ with $5 \% \mathrm{CO}_{2}$, dimethyl sulfoxide was added to each well to dissolve the formazan crystals. MTT reduction was determined by measuring the absorbance of each well at $490 \mathrm{~nm}$ using a microplate spectrophotometer (Bio-Rad Laboratories, Inc., Hercules, CA, USA).

Luciferase reporter gene assay. (CAGA)12-Luc-reporter plasmid along with an internal control (pRL-TK vector; Promega Corporation) were transfected into HEK293T cells using Vigofect (Vigorous Inc., Beijing, China), according to the manufacturer's instructions. After 24-h transfection, HEK293T were stimulated with different concentrations $(0$, $0.1,0.01,0.001$ or $0.0001 \mu \mathrm{M}$ ) of isopsoralen. Isopsoralen stimulation lasted for $12 \mathrm{~h}$ and then reporter activity was determined by the Dual-Luciferase Assay System (Vigorous Inc.). The Luciferase activity was measured using a Luminescence Counter Top Count NXT (Packard Instrument Company, Inc., Meriden, CT, USA). Firefly luciferase activity was normalized against Renilla luciferase activity.

Cell grouping. A total of $2 \times 10^{5}$ cells were transferred into five plates (60-mm cell culture dishes). Waste liquid was aspirated from each plate when the cells reached $60 \%$ confluence. Subsequently, $3 \mathrm{ml}$ DMEM supplemented with 10\% FBS and penicillin $(100 \mathrm{U} / \mathrm{ml})$ and streptomycin $(100 \mathrm{U} / \mathrm{ml})$ was added and all cells were incubated in an incubator at $37^{\circ} \mathrm{C}$ in an atmosphere containing $5 \% \mathrm{CO}_{2}$. Synchronization was performed for $24 \mathrm{~h}$ to cause cell quiescence at the G0 stage. The cells in each plate were divided into the following five groups: The control (0 $\mu \mathrm{M}$ isopsoralen), $0.1 \mu \mathrm{M}(0.1 \mu \mathrm{M}$ isopsoralen), $0.01 \mu \mathrm{M}(0.01 \mu \mathrm{M}$ isopsoralen), $0.001 \mu \mathrm{M}(0.001 \mu \mathrm{M}$ isopsoralen) and $0.0001 \mu \mathrm{M}(0.0001 \mu \mathrm{M}$ isopsoralen) groups. The control group was cultured in DMEM medium supplemented with $10 \%$ FBS. The other 4 groups were cultured in DMEM supplemented with $10 \%$ FBS containing the respective concentrations of isopsoralen. Each group was incubated at $37^{\circ} \mathrm{C}$ with $5 \% \mathrm{CO}_{2}$. Each group of cells were stimulated by isopsoralen for $72 \mathrm{~h}$ in a $60-\mathrm{mm}$ plastic dish and then the total RNA and protein were extracted and used for RT-PCR or western blotting.

Reverse transcription-polymerase chain reaction (RT-PCR). Total cellular RNA was prepared from MC3T3-E1 cells using 
TRIzol reagent (Invitrogen; Thermo Fisher Scientific, Inc.). The concentration and purity of total RNA were evaluated by measuring the $260 / 280 \mathrm{~nm}$ ratios from the cells following 72-h incubation at $37^{\circ} \mathrm{C}$ with $5 \% \mathrm{CO}_{2}$. Total RNA (5 $\left.\mu \mathrm{g}\right)$ was denatured at $70^{\circ} \mathrm{C}$ for $5 \mathrm{~min}$ and then rapidly chilled on ice. Each RT reaction mixture contained $5 \mu \mathrm{g}$ total RNA, $1 \mu \mathrm{l}$ oligo (dT) 15 primer (SBS Genetech Co., Ltd., Beijing, China), $1 \mu \mathrm{l}$ dNTPs, $4 \mu 1$ 5X M-MLV buffer, $1 \mu 1$ RNA enzyme inhibitors and $20 \mu \mathrm{l}$ DEPC water. The reaction mixture was mixed by centrifugation at $300 \mathrm{x} \mathrm{g}$ for $5 \mathrm{sec}$, incubated at $42^{\circ} \mathrm{C}$ for $60 \mathrm{~min}$, then at $95^{\circ} \mathrm{C}$ for $5 \mathrm{~min}$, cooled on ice for $5 \mathrm{~min}$ and stored at $-20^{\circ} \mathrm{C}$. The final reaction mixture for cDNA PCR included $36.5 \mu \mathrm{l}$ DEPC water, $5 \mu \mathrm{l}$ 10X reaction buffer, $2 \mu \mathrm{l}$ upstream and downstream primers of each target, $1 \mu \mathrm{l}$ dNTPs, $3 \mu 1$ reverse transcription product and $0.5 \mu 1$ Taq DNA polymerase $(3 \mathrm{U} / \mu \mathrm{l})$. The above reaction solution was incubated in a PCR machine, and the following PCR reaction conditions were employed: $94^{\circ} \mathrm{C}$ for $5 \mathrm{~min} ; 28$ cycles of $94^{\circ} \mathrm{C}$ for $30 \mathrm{sec}$, $59^{\circ} \mathrm{C}$ for $30 \mathrm{sec}$ and $72^{\circ} \mathrm{C}$ for $45 \mathrm{sec}$; followed by $10 \mathrm{~min}$ at $72^{\circ} \mathrm{C}$. The primers used for PCR amplification were as follows: Type 1 collagen forward, 5'-GACGCCATCAAGGTC TACTG-3' and reverse, 5'-ACGGGAATCCATCGGTCA-3' (product size $154 \mathrm{bp}$ ) and GAPDH forward, 5'-GCATTGTGG AAGGGCTCA-3' and reverse, 5'-GGGTAGGAACACGGA AGG-3' (product size 207 bp) (28). The above primers were synthesized by Invitrogen (Thermo Fisher Scientific, Inc.). Experiments were performed in triplicate and GAPDH was considered the internal reference.

Semi-quantitative analysis of the amplification product. The PCR products $(10-\mu 1$ volume for each product) were analyzed by $1 \%$ agarose gel electrophoresis and stained with GoldView. The optical density of the electrophoretic bands was scanned using an (AlphaImager 1220; Alpha Innotech, San Leandro, CA, USA). The ratio of the electrophoretic band optical density of collagen and of GAPDH were obtained to determine the relative mRNA expression level.

Western blot analysis. Total protein was extracted from the cells following 72 -h incubation at $37^{\circ} \mathrm{C}$ with $5 \% \mathrm{CO}_{2}$. To extract the cytoplasmic protein, $200 \mu \mathrm{l}$ cytosolic lysate was added to each culture and cultures were placed on ice for $30 \mathrm{~min}$. Cells were detached with a cell scraper, transferred into a pre-cooled Eppendorf (EP) tube and centrifuged at 8,000 x g for $10 \mathrm{~min}$ at $4^{\circ} \mathrm{C}$. The supernatant was immediately transferred into a pre-cooled EP tube and mixed with an equal volume of buffer solution. The sample was subsequently boiled at $100^{\circ} \mathrm{C}$ for $10 \mathrm{~min}$ and then stored at $-20^{\circ} \mathrm{C}$. A total of $10 \mu 1$ supernatant was used to determine the lysate protein concentration via the BCA kit (Beyotime Institute of Biotechnology) and the rest of supernatant was stored at $-80^{\circ} \mathrm{C}$.

Aliquots of denatured protein liquid $(30 \mu \mathrm{g})$ were loaded and separated by SDS-PAGE (10\% separation gel, $4 \%$ concentrated gel). The proteins from the gel were then blotted onto a nitrocellulose membrane (EMD Millipore, Billerica, MA, USA). The membrane was then incubated overnight at $4^{\circ} \mathrm{C}$. Anti-Smad7 (1:500-1,000; sc-11392) and anti-GAPDH $(1: 1,000$; sc-365062) primary antibodies were added to the blots and incubated at $4{ }^{\circ} \mathrm{C}$ overnight. Once the membrane was washed three times for $10 \mathrm{~min}$ each time in Tris-buffered saline with Tween-20 (TBST), secondary antibodies polyclonal horseradish peroxidase-conjugated goat anti-rabbit (ZB-2308) and goat anti-mouse immunoglobulins (ZB-2305; Beijing Zhongshan Golden Bridge Biotechnology Co., Ltd.) were subsequently added and the membrane was incubated at $37^{\circ} \mathrm{C}$ for $1 \mathrm{~h}$. The membrane was washed again using the 1X TBST buffer for 10 min three times and then stained with enhanced chemiluminescence reagent (Amersham Biosciences Corp., Piscataway, NJ, USA), and exposed to X-ray film. Image $\mathrm{J}$ analysis software 1.42q (National Institutes of Health, Bethesda, MA, USA) was used to conduct the image analysis.

Statistical analysis. Data are presented as mean \pm standard error. Three independent biological repeats were performed for each treatment. Single factor variance analysis was used to analyze all experimental data via the statistical software package SPSS 13.0 (SPSS, Inc., Chicago, IL, USA). P<0.05 was considered to indicate a statistically significant difference.

\section{Results}

Detection of the effect of isopsoralen on MC3T3-E1 cell viability using the MTT method. MTT assay revealed that MC3T3-E1 cell viability exhibited a dose-dependent increase with decreasing isopsoralen concentrations and that MC3T3-E1 cell viability was significantly increased following treatment with $0.01,0.001$ and $0.0001 \mu \mathrm{M}$ isopsoralen compared with the control group $(\mathrm{P}<0.05$; Fig. 1).

Effect of isopsoralen on the relative luciferase activity of the $T G F-\beta 1$ reporter gene. Compared with the control group, 0.01 , 0.001 and $0.0001 \mu \mathrm{M}$ isopsoralen treatment was capable of significantly increasing luciferase activity and activating the TGF- $\beta 1$ reporter gene ( $\mathrm{P}<0.05$; Fig. 2$)$. There was no significant difference between $0.01,0.001$ and $0.0001 \mu \mathrm{M}$ isopsoralen treatment groups on the relative luciferase activity (Fig. 2).

Effect of isopsoralen on type I collagen mRNA expression levels in pre-osteoblast cells. RT-PCR assays revealed the effect of isopsoralen on MC3T3-E1 cells after $72 \mathrm{~h}$ compared with the control group. Doses of 0.01, 0.001 and $0.0001 \mu \mathrm{M}$ isopsoralen significantly promoted type I collagen mRNA expression levels in MC3T3-E1 cells after $72 \mathrm{~h}$ of stimulation compared with the control group $(\mathrm{P}<0.05$; Fig. 3$)$.

Effect of isopsoralen on Smad7 protein expression levels in pre-osteoblast cells. Western blot analysis results revealed that, after MC3T3-E1 cells were treated with various concentrations of isopsoralen for $72 \mathrm{~h}$, Smad7 protein expression levels were significantly decreased following treatment with $0.01,0.001$ and $0.0001 \mu \mathrm{M}$ isopsoralen compared with the control group ( $\mathrm{P}<0.05$; Fig. 4).

\section{Discussion}

Estrogen protects bones by promoting calcitonin secretion, inhibiting bone resorption, facilitating intestinal calcium absorption and accelerating bone proliferation (29). A previous study indicated that hip fractures caused by PM-OP are associated with aging and declining levels of estrogen, with declining 


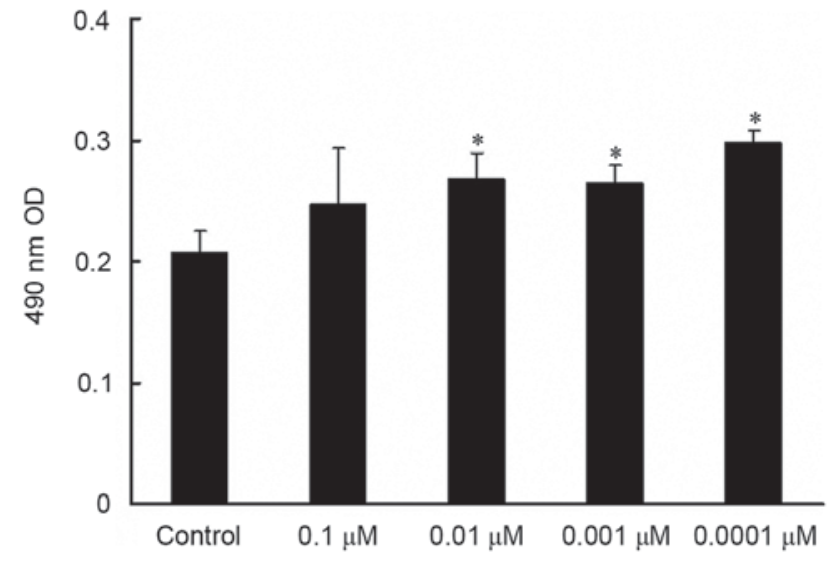

Figure 1. Effect of isopsoralen on MC3T3-E1 cell viability. MC3T3-E1 cell viability was determined after incubation with $0,0.1,0.01,0.001$ or $0.0001 \mu \mathrm{M}$ isopsoralen for $72 \mathrm{~h}$. Absorbance was detected at $490 \mathrm{~nm}$. ${ }^{*} \mathrm{P}<0.05$ vs. control group. OD, optical density.

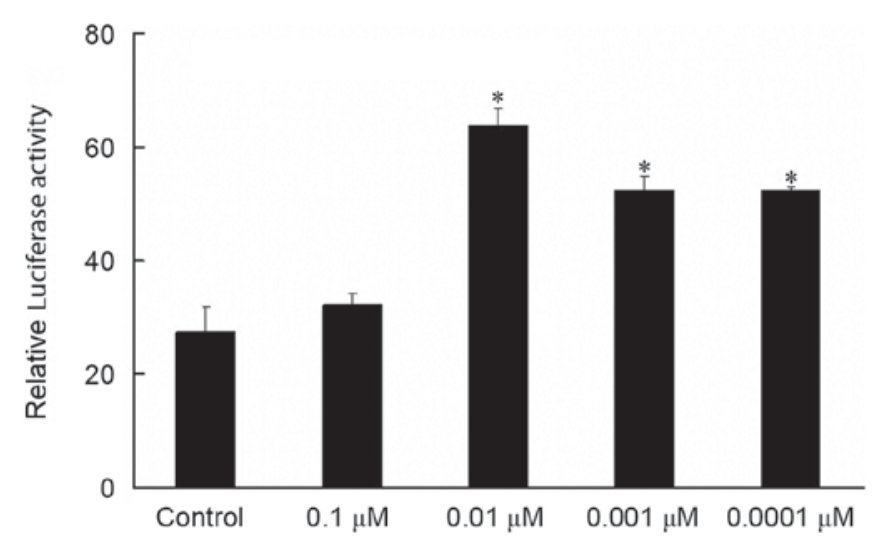

Figure 2. Effect of isopsoralen on TGF- $\beta$ reporter gene activity. TGF- $\beta 1$ reporter gene activity was determined after incubation with $0,0.1,0.01,0.001$ or $0.0001 \mu \mathrm{M}$ isopsoralen. ${ }^{*} \mathrm{P}<0.05$ vs. control group. TGF, transforming growth factor.

estrogen levels being the primary cause (30). Hormone replacement therapy (HRT) has a positive effect on treating PM-OP, as shown by years of clinical practice (31-33). Some older women are administered long-term estrogen to protect against osteoporosis $(34,35)$. Currently, estrogen replacement therapy is an effective method for treating PM-OP. However, estrogen is not suitable for all postmenopausal women and long-term application of estrogen may result in increased risks of high blood coagulation status, high blood pressure, edema, breast cancer and endometrial cancer (36). Studies have demonstrated that the use of HRT for $>5$ years can significantly increase the mortality rate of breast cancer (37). Some patients with breast cancer who receive aromatase inhibitor therapy are more vulnerable to osteoporosis symptoms; therefore, the use of hormones for treating osteoporosis in such patients should be avoided (38). As a result, HRT administration should be limited to the shortest possible duration and alternatives to HRT should be used to treat menopausal syndromes (39). Consequently, the identification of natural agents with minimal side effects is a novel and exciting field for the treatment of PM-OP.

The imbalance of bone formation and resorption is an important reason for the occurrence of PM-OP that is caused
A

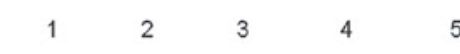

Type I Collagen

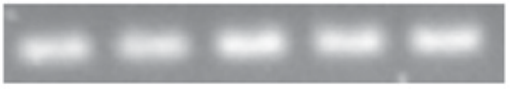

GAPDH

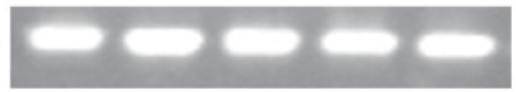

B

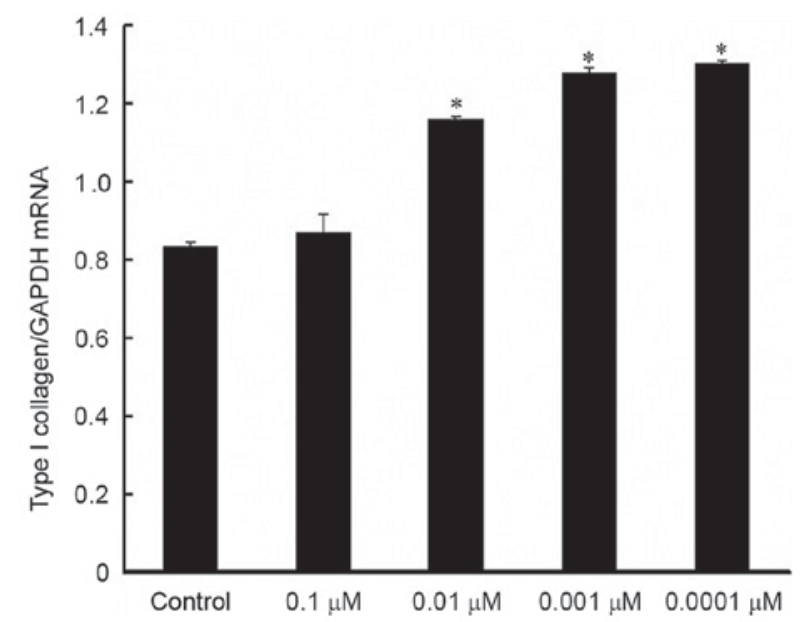

Figure 3. Effect of isopsoralen on type I collagen mRNA expression levels in pre-osteoblast cells. (A) Type I collagen mRNA expression levels in MC3T3-E1 cells were detected by reverse transcription-polymerase chain reaction after stimulation with $0,0.1,0.01,0.001$ or $0.0001 \mu \mathrm{M}$ isopsoralen for $72 \mathrm{~h}$. (B) Semi-quantitative analysis revealed the relative mRNA expression levels. ${ }^{*} \mathrm{P}<0.05$ vs. control group. 1, control group; $2,0.1 \mu \mathrm{M}$ isopsoralen group; 3, $0.01 \mu \mathrm{M}$ isopsoralen group; 4, $0.001 \mu \mathrm{M}$ isopsoralen group; 5, $0.0001 \mu \mathrm{M}$ isopsoralen group.

A

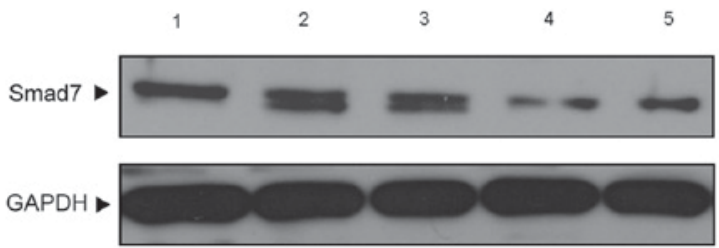

B

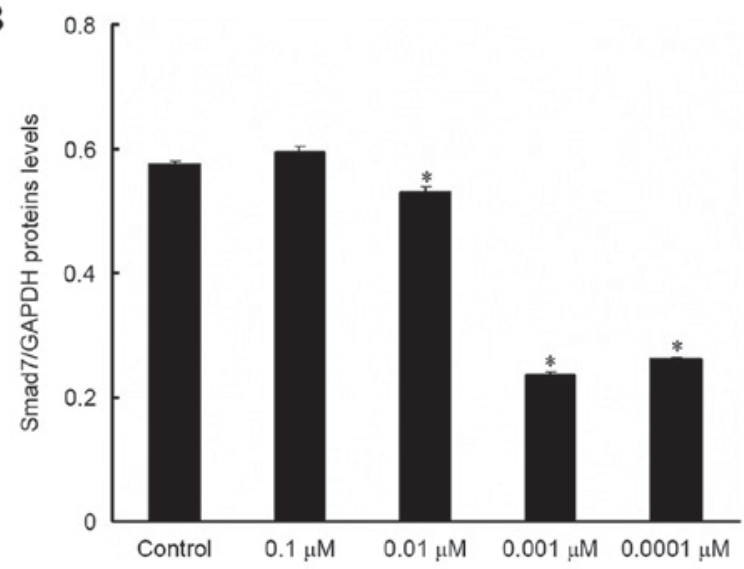

Figure 4. Effect of isopsoralen on Smad7 protein expression levels in in pre-osteoblast cells. (A) Smad7 protein expression levels in MC3T3-E1 cells were detected by western blot analysis after stimulation with, $0,0.1,0.01$, 0.001 or $0.0001 \mu \mathrm{M}$ isopsoralen for $72 \mathrm{~h}$. (B) The relative protein expression levels were determined. ${ }^{*} \mathrm{P}<0.05$ vs. control group. Smad, mothers against decapentaplegic homolog; 1 , control group; $2,0.1 \mu \mathrm{M}$ isopsoralen group; 3 , $0.01 \mu \mathrm{M}$ isopsoralen group; 4, $0.001 \mu \mathrm{M}$ isopsoralen group; $5,0.0001 \mu \mathrm{M}$ isopsoralen group. 


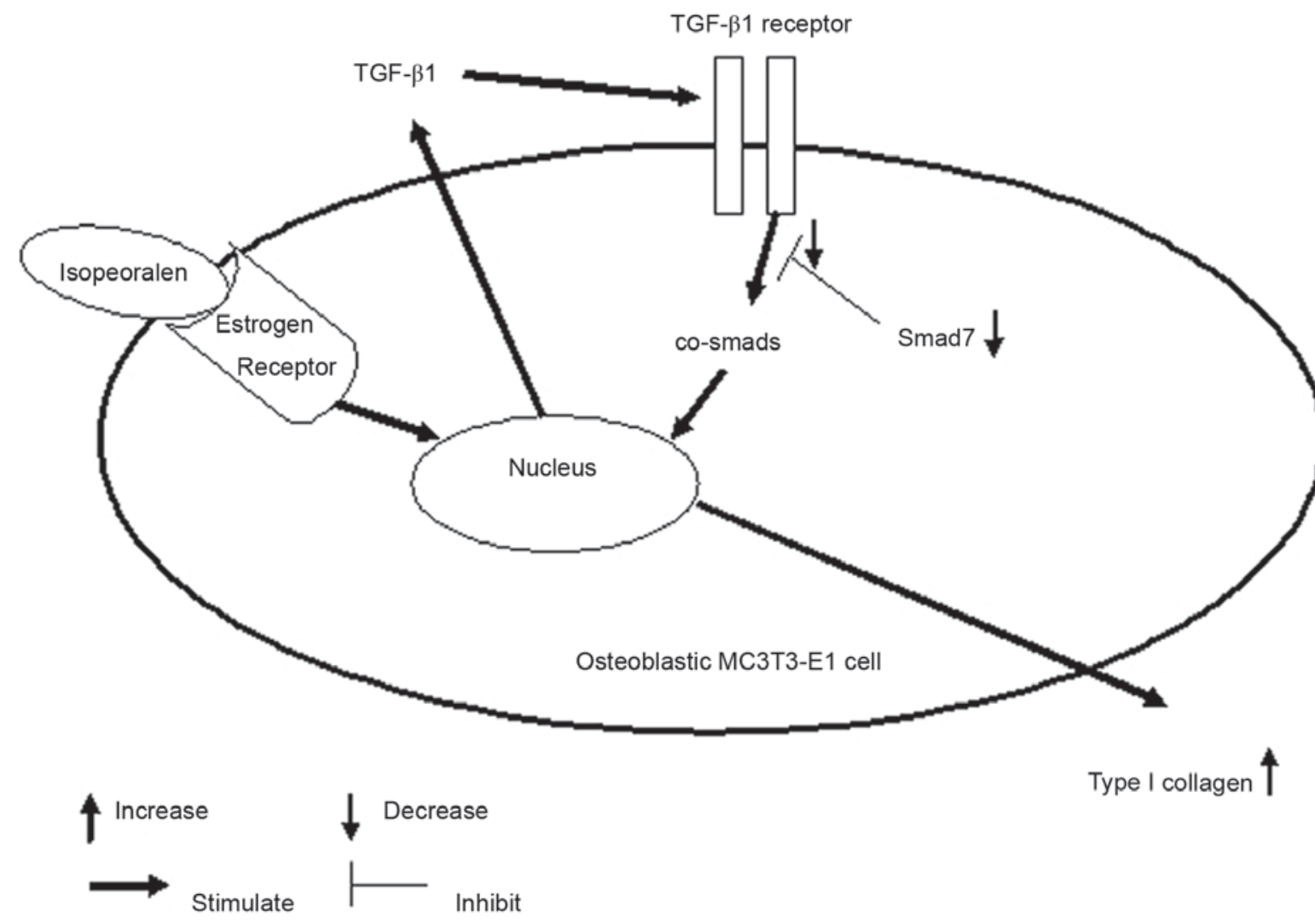

Figure 5. Effect of Smad7 in osteoblastic MC3T3-E1 cells stimulated with isopsoralen. Phytoestrogen isopsoralen promotes TGF- $\beta 1$ signaling pathway transduction by inhibiting Smad7 protein expression, which results in increased type I collagen secretion. Smad, mothers against decapentaplegic homolog; TGF, transforming growth factor.

by decreased estrogen levels. This results in a decrease in TGF- $\beta 1$ in postmenopausal women, which may predispose these women to osteoporosis and to delayed wound repair (40). TGF- $\beta 1$ has crucial roles in osteoblast proliferation and differentiation, as well as in matrix production (41). Previously, TGF- $\beta 1$ was injected into rat periosteum and was indicated to improve the formation of new bone (42). The uncoupling of bone resorption and formation caused by decreased estrogen levels is associated with alterations in TGF- $\beta 1$ and its signaling pathway in bone tissue $(43,44)$. The CAGA box is essential and sufficient for TGF- $\beta$ signal induction and CAGA elements are widely used motifs in TGF- $\beta$-regulated transcription (45). The present study demonstrated that specific concentrations of isopsoralen significantly increased TGF- $\beta 1$ reporter gene luciferase activity. The mechanism by which isopsoralen stimulates TGF- $\beta 1$ cell signaling has not been investigated; however, its mechanism may be attributed to the similarity of the structure of phytoestrogens to that of mammalian estrogen and to the estrogenic activities of phytoestrogens (46). The ability of estrogen to induce an increase TGF- $\beta 1$ expression has been reported previously $(40,47)$.

Phytoestrogens are a group of plant-derived substances that are structurally and functionally similar to estradiol and are able to bind to the estrogen receptor and elicit estrogenic activities $(48,49)$. Considering these factors, it is possible that phytoestrogens may be an alternative to postmenopausal HRT that may ameliorate discomfort and increased risk of disease. Isopsoralen is a type of phytoestrogen and may therefore function by binding to the estrogen receptor, thus promoting
TGF- $\beta 1$ formulation and stimulating the TGF- $\beta 1$ signaling pathway. However, few studies have examined the effect of isopsoralen on the TGF- $\beta 1$ signaling pathway and collagen secretion in osteoblasts. Smad7 is an important inhibitory factor in the downstream transmission path of TGF- $\beta$ signaling pathways in osteoblasts (50). Smad7 binds with the activated $\mathrm{T} \beta \mathrm{RI}$ receptor and induces biological inhibition (51), which is an important mechanism for various drug treatments of osteoporosis that function by altering the expression of related factors in the TGF- $\beta$ signaling pathway in bone tissue $(52,53)$. Previous studies have demonstrated that estrogen has important effects on TGF- $\beta 1$ expression in bone tissue and promotes a series of changes in osteoblast proliferation at the molecular biological level. Increased bone collagen secretion in addition to other changes maintain the relative stability of the bone mass $(40,47)$. The present study showed that at specific concentrations, isopsoralen significantly increased osteoblast viability, decreased Smad7 expression, which promoted TGF- $\beta$ signaling and increased collagen synthesis. Thus, isopsoralen may be a potential agent for improving imbalances of collagen metabolism in PM-OP. In conclusion, the present study demonstrated that phytoestrogen isopsoralen promotes TGF- $\beta$ signaling pathway transduction by inhibiting Smad7 protein expression and increasing type I collagen secretion (Fig. 5). Therefore, isopsoralen may be useful in the treatment of PM-OP. The present study provides the scientific basis of the molecular mechanisms by which isopsoralen acts as a type of phytoestrogen. The present findings indicate that isopsoralen may be used to treat PM-OP and may contribute to 
the research and development of novel agents for the treatment of PM-OP.

\section{Acknowledgements}

The present study was supported by the Fund of Beijing Municipal Administration of Hospitals Incubating Program (grant no. PZ, 2016013), the Cooperation Fund of Basic and Clinical Research of Capital Medical University (grant no. 16JL24), the Fund for Beijing Science and Technology Development of TCM (grant no. QN2016-24) and the Fund of Beijing Hospital of Traditional Chinese Medicine (grant no. YJ-201722).

\section{References}

1. Maeda SS and Lazaretti-Castro M: An overview on the treatment of postmenopausal osteoporosis. Arq Bras Endocrinol Metabol 58: 162-171, 2014.

2. Janiszewska M, Kulik TB, Dziedzic MA and ŻołnierczukKieliszek D: The contemporary look at the problem of recognizing and diagnosing postmenopausal osteoporosis and eliminating the risk of a fall. Prz Menopauzalny 13: 42-47, 2014

3. Jaha H, Husein D, Ohyama Y, Xu D, Suzuki S, Huang GT and Mochida Y: N-terminal Dentin Sialoprotein fragment induces type I collagen production and upregulates dentinogenesis marker expression in osteoblasts. Biochem Biophys Rep 6 : 190-196, 2016.

4. Rydziel S, Varghese S and Canalis E: Transforming growth factor betal inhibits collagenase 3 expression by transcriptional and post-transcriptional mechanisms in osteoblast cultures. J Cell Physiol 70: 145-152, 1997.

5. Katz LH, Li Y, Chen JS, Muñoz NM, Majumdar A, Chen J and Mishra L: Targeting TGF-beta signaling in cancer. Expert Opin Ther Targets 17: 743-760, 2013.

6. López-Casillas F, Wrana JL and Massagué J: Betaglycan presents ligand to the TGF beta signaling receptor. Cell 73: 1435-1444, 1993.

7. Wrana JL, Attisano L, Wieser R, Ventura F and Massagué J: Mechanism of activation of the TGF-beta receptor. Nature 370: 341-347, 1994

8. Heldin CH, Miyazono K and ten Dijke P: TGF-beta signalling from cell membrane to nucleus through SMAD proteins. Nature 390: 465-471, 1997.

9. Derynck R, Zhang Y and Feng XH: Smads: Transcriptional activators of TGF-beta responses. Cell 95: 737-740, 1998.

10. Wu M, Chen G and Li YP: TGF- $\beta$ and BMP signaling in osteoblast, skeletal development, and bone formation, homeostasis and disease. Bone Res 4: 16009, 2016.

11. Steiner RD, Adsit J and Basel D: COL1A1/2-related osteogenesis imperfecta. In: GeneReviews. Pagon RA, Adam MP, Ardinger HH, Wallace SE, Amemiya A, Bean LJH, Bird TD, Ledbetter N, Mefford HC, Smith RJH and Stephens K (eds) University of Washington, Seattle, WA, 2005.

12. Saito M and Marumo K: Collagen cross-links as a determinant of bone quality: A possible explanation for bone fragility in aging, osteoporosis, and diabetes mellitus. Osteoporos Int 21: 195-214, 2010.

13. Gelse K, Pöschl E and Avinger T: Collagens-structure, function, and biosynthesis. Adv Drug Deliv Rev 55: 1531-1546, 2003.

14. Chen $\mathrm{G}$, Deng $\mathrm{C}$ and $\mathrm{Li}$ YP: TGF- $\beta$ and BMP signaling in osteoblast differentiation and bone formation. Int J Biol Sci 8: 272-288, 2012.

15. Mukasa C, Nomura M, Tanaka T, Tanaka K, Nishi Y, Okabe T, Goto $\mathrm{K}$, Yanase $\mathrm{T}$ and Nawata $\mathrm{H}$ : Activin signaling through type IB activin receptor stimulates aromatase activity in the ovarian granulosa cell-like human granulose (KGN) cells. Endocrinology 144: 1603-1611, 2003.

16. Arjmandi $\mathrm{BH}$ : The role of phytoestrogens in the prevention and treatment of osteoporosis in ovarian hormone deficiency. J Am Coll Nutr 20 (5 Suppl): 398S-402S; 417S-420S, 2001.

17. Komm BS, Terpening CM, Benz DJ, Graeme KA, Gallegos A, Korc M, Greene GL, O'Malley BW and Haussler MR: Estrogen binding, receptor mRNA, and biologic response in osteoblast-like osteosarcoma cells. Science 241: 81-84, 1988.
18. Majeska RJ, Ryaby JT and Einhorn TA: Direct modulation of osteoblastic activity with estrogen. J Bone Joint Surg Am 76: 713-721, 1994.

19. Benz DJ, Haussler MR and Komm BS: Estrogen binding and estrogenic responses in normal human osteoblast-like cells. J Bone Miner Res 6: 531-541, 1991.

20. Virk-Baker MK, Nagy TR and Barnes S: Role of phytoestrogens in cancer therapy. Planta Med 76: 1132-1142, 2010.

21. Yamaguchi M and Sugimoto E: Stimulatory effect of genistein and daidzein on protein synthesis in osteoblastic MC3T3-E1 cells: Activation of aminoacyl-tRNA synthetase. Mol Cell Biochem 214: 97-102, 2000

22. Wu J, Wang XX, Takasaki M, Ohta A, Higuchi M and Ishimi Y: Cooperative effects of exercise training and genistein administration on bone mass in ovariectomized mice. J Bone Miner Res 16: 1829-1836, 2001.

23. Zhao LH, Wu MH and Xiang BR: Analysis of Psoralea corylifolia L. fruits in different regions. Chem Pharm Bull (Tokyo) 53, 1054-1057, 2005.

24. Chen X, Kong L, Su X, Pan C, Ye M and Zou H: Integration of ion-exchange chromatography fractionation with reversed-phase liquid chromatography-atmospheric pressure chemical ionization mass spectrometer and matrix-assisted laser desorption/ionization time-of-flight mass spectrometry for isolation and identification of compounds in Psoralea corylifolia. J Chromatogr A 1089: 87-100, 2005.

25. Wang D, Yang G, Engelhardt H and Zhang H: Micellar electrokinetic capillary chromatography of psoralen and isopsoralen. Electrophoresis 20: 1895-1899, 1999.

26. Xin D, Wang H, Yang J, Su YF, Fan GW, Wang YF, Zhu Y and Gao XM: Phytoestrogens from Psoralea corylifolia reveal estrogen receptor-subtype selectivity. Phytomedicine 17: 126-131, 2010.

27. Ming LG, Cheng KM, Ge BF, Ma HP and Zai YK: Effect of isopsoralen on the proliferation and differentiate of osteoblasts in vitro. Zhong Yao Cai 34: 404-408, 2011 (In Chinese).

28. He Z, Feng L, Zhang X, Geng Y, Parodi DA, Suarez-Quian C and Dym M: Expression of Colla1, Colla2 and procollagen I in germ cells of immature and adult mouse testis. Reproduction 130: 333-341, 2005.

29. Lanyon L, Armstrong V, Ong D, Zaman G and Price J: Is estrogen receptor alpha key to controlling bones' resistance to fracture? J Endocrinol 182: 183-191, 2004.

30. László A: Postmenopausal osteoporosis. Orv Hetil 145: 3-13, 2004 (In Hungarian).

31. Gallagher JC: Moderation of the daily dose of HRT: Prevention of osteoporosis. Maturitas 33 (Suppl 1): S57-S63, 1999.

32. Pardini D: Menopausal hormone therapy. Arq Bras Endocrinol Metabol 51: 938-942, 2007 (In Portuguese).

33. Prelevic GM, Kocjan T and Markou A: Hormone replacement therapy in postmenopausal women. Minerva Endocrinol 30: 27-36, 2005.

34. Gonnelli S, Cepollaro C, Pondrelli C, Martini S, Monaco R and Gennari C: The usefulness of bone turnover in predicting the response to transdermal estrogen therapy in postmenopausal osteoporosis. J Bone Miner Res 12: 624-631, 1997.

35. Fitzpatrick LA: Estrogen therapy for postmenopausal osteoporosis. Arq Bras Endocrinol Metabol 50: 705-719, 2006.

36. Dören M and Samsioe G: Prevention of postmenopausal osteoporosis with oestrogen replacement therapy and associated compounds: Update on clinical trials since 1995. Hum Reprod Update 6: 419-426, 2000.

37. Pentti K, Honkanen R, Tuppurainen MT, Sandini L, Kröger H and Saarikoski S: Hormone replacement therapy and mortality in 52- to 70-year-old women: The kuopio osteoporosis risk factor and prevention study. Eur J Endocrinol 154: 101-107, 2006.

38. Nikander E, Metsä-Heikkilä M, Ylikorkala O and Tiitinen A: Effects of phytoestrogens on bone turnover in postmenopausal women with a history of breast cancer. J Clin Endocrnol Metab 89: 1207-1212,2004.

39. Deady J: Clinical monograph: Hormone replacement therapy. J Manag Care Pharm 10: 33-47, 2004.

40. Ashcroft GS, Dodsworth J, van Boxtel E, Tarnuzzer RW, Horan MA, Schultz GS and Ferguson MW: Estrogen accelerates cutaneous wound healing associated with an increase in TGF-beta1 levels. Nat Med 3: 1209-1215, 1997.

41. Bonewald LF and Mundy GR: Role of transforming growth factor-beta in bone remodeling. Clin Orthop Relat Res: 261-276, 1990. 
42. Noda M and Camilliere JJ: In vivo stimulation of bone formation by transforming growth factor-beta. Endocrinology 124 : 2991-2994, 1989.

43. Marie P: Growth factors and bone formation in osteoporosis: Roles for IGF-I and TGF-beta. Rev Rhum Engl Ed 64: 44-53, 1997.

44. Yamada Y, Miyauchi A, Goto J, Takagi Y, Okuizumi H, Kanematsu M,Hase M, Takai H,Harada A and Ikeda K: Association of a polymorphism of the transforming growth factor-betal gene with genetic susceptibility to osteoporosis in postmenopausal Japanese wome. J Bone Miner Res 13: 1569-1576, 1998.

45. Dennler S, Itoh S, Vivien D, ten Dijke P, Huet S and Gauthier JM: Direct binding of Smad3 and Smad4 to critical TGF beta-inducible elements in the promoter of human plasminogen activator inhibitor-type 1 gene. EMBO J 17: 3091-3100, 1998

46. Taxvig C, Elleby A, Sonne-Hansen K, Bonefeld-Jørgensen EC, Vinggaard AM, Lykkesfeldt AE and Nellemann C: Effects of nutrition relevant mixtures of phytoestrogens on steroidogenesis, aromatase, estrogen, and androgen activity. Nutr Cancer 62: $122-131,2010$

47. Estai MA, Suhaimi F, Das S, Shuid AN, Mohamed Z and Soelaiman IN: Expression of TGF- $\beta 1$ in the blood during fracture repair in an estrogen-deficient rat model. Clinics (Sao Paulo) 66 2113-2119, 2011
48. Limer JL and Speirs V: Phyto-oestrogens and breast cancer chemoprevention. Breast Cancer Res 6: 119-127, 2004.

49. Knight DC and Eden JA: A review of the clinical effects of phytoestrogens. Obstet Gynecol 87: 897-904, 1996.

50. Kavsak P, Rasmussen RK, Causing CG, Bonni S, Zhu H, Thomsen GH and Wrana JL: Smad7 binds to Smurf2 to form an E3 ubiquitin ligase that targets the TGF beta receptor for degradation. Mol Cell 6: 1365-1375, 2000.

51. Souchelnytskyi S, Nakayama T, Nakao A, Morén A, Heldin $\mathrm{CH}$, Christian JL and ten Dijke P: Physical and functional interaction of murine and Xenopus Smad7 with bone morphogenetic protein receptors and transforming growth factor-beta receptors. J Biol Chem 273: 25364-25370, 1998

52. Peleg S, Uskokovic M, Ahene A, Vickery B and Avnur Z: Cellular and molecular events associated with the bone-protecting activity of the noncalcemic vitamin D analog Ro-26-9228 in osteopenic rats. Endocrinology 143: 1625-1636, 2002.

53. Bord S, Beavan S, Ireland D, Horner A and Compston JE: Mechanisms by which high-dose estrogen therapy produces anabolic skeletal effects in postmenopausal women: Role of locally produced growth factors. Bone 29: 216-222, 2001. 